Int. J. Morphol.,

35(2):651-653, 2017

\title{
A Case of Anomalous Horizontal Fissure and Hypoplastic Middle Lobe of the Right Lung
}

\author{
Un Caso de Fisura Horizontal Anómala y Lóbulo Medio Hipoplásico del Pulmón Derecho
}

Keishi Okamoto'; Tetsuaki Wakebe ${ }^{1,3}$; Kazunobu Saiki' ${ }^{1}$ Yoshitaka Manabe ${ }^{2}$ \& Toshiyuki Tsurumoto ${ }^{1}$

OKAMOTO, K.; WAKEBE, T.; SAIKI, K.; MANABE, Y. \& TSURUMOTO, T. A case of anomalous horizontal fissure and hypoplastic middle lobe of the right lung. Int. J. Morphol., 35(2):651-653, 2017.

SUMMARY: During dissection practice for medical students at Nagasaki University, a horizontal fissure and hypoplastic middle lobe were encountered in the right lung of an 81-year-old Japanese female. In a normal right lung, the horizontal fissure is situated anterior to the oblique fissure. On the contrary, in the present case, the horizontal fissure was situated posterior to the oblique fissure. We identified a small, additional lobe on the medial surface of this lung. It was situated in the medial part of the oblique fissure, and was determined to be a small hypoplastic middle lobe. As a result of the hypoplasia of the middle lobe, the original horizontal fissure may have disappeared from the anterior surface. The horizontal fissure, in this case, may be a compensatory additional fissure that developed within the inferior lobe. This horizontal fissure was incomplete, both in length and depth. The left lung was normal. This case might be very rare; however, it may aid in the understanding of normal lung development. Therefore, we report this case, including its bronchial branching and vascular distribution.

KEY WORDS: Lung; Horizontal fissure of right lung; Hypoplastic middle lobe; Oblique fissure; Anomaly.

\section{INTRODUCTION}

In the human lung, the right lung is divided into three lobes by two fissures, the oblique and horizontal fissures. The left lung is divided into two lobes by an oblique fissure. Additional fissures occasionally occur, although they are usually short (Hollinshead, 1971; Bergman et al., 1988; Arai \& Shiozawa, 1992; Murakami, 2000). In the present case, the right lung had two fissures. However, they exhibited an atypical structural relationship. In a normal right lung, the horizontal fissure is situated in anterior to the oblique fissure, whereas, in this case, the horizontal fissure was situated behind the oblique fissure. We examined the right lung to clarify this phenomenon.

The present study was performed on a cadaver donated to our institution for student dissection and research. The study was conducted in accordance with the ethical standards of the Declaration of Helsinki of 1964, as revised in 2013.

\section{CASE REPORT}

This case was found in an 81-year-old Japanese female during dissection practice at Nagasaki University School of Medicine. We noticed an anomalous horizontal fissure on the right lung after removal of the lung from the thorax. Drawings and photographs were made to record the findings. Then the intrapulmonary distribution of the bronchial and pulmonary vessels was examined by removing the parenchymal tissue of the lung.

In the present case, the right lung had a horizontal fissure posterior to the oblique fissure (Fig. 1a). However, the horizontal fissure was incomplete in depth and length. It did not reach the posterior surface of the lung. When the oblique fissure was opened, a small gland-like tissue was detected within the fissure (Fig. 1b). The dimensions of the tissue were $20 \mathrm{~mm}$ in height, $45 \mathrm{~mm}$ in width, and $50 \mathrm{~mm}$ in anteroposterior length. The anterior edge was thin (Fig. 1c). The gland-like tissue was clearly visible on the medial side

\footnotetext{
${ }^{1}$ Department of Macroscopic Anatomy, Unit of Basic Medical Sciences, Graduate School of Biomedical Science, Nagasaki University, Nagasaki, Japan. ${ }^{2}$ Department of Oral Anatomy and Dental Anthropology

${ }^{3}$ Nagasaki Medical College,
} 
of the right lung (Fig. 2a). We considered that this tissue was a hypoplastic middle lobe. The bronchial and the pulmonary vessels were distributed in this hypoplastic middle lobe (Figs. 2b, 2c).
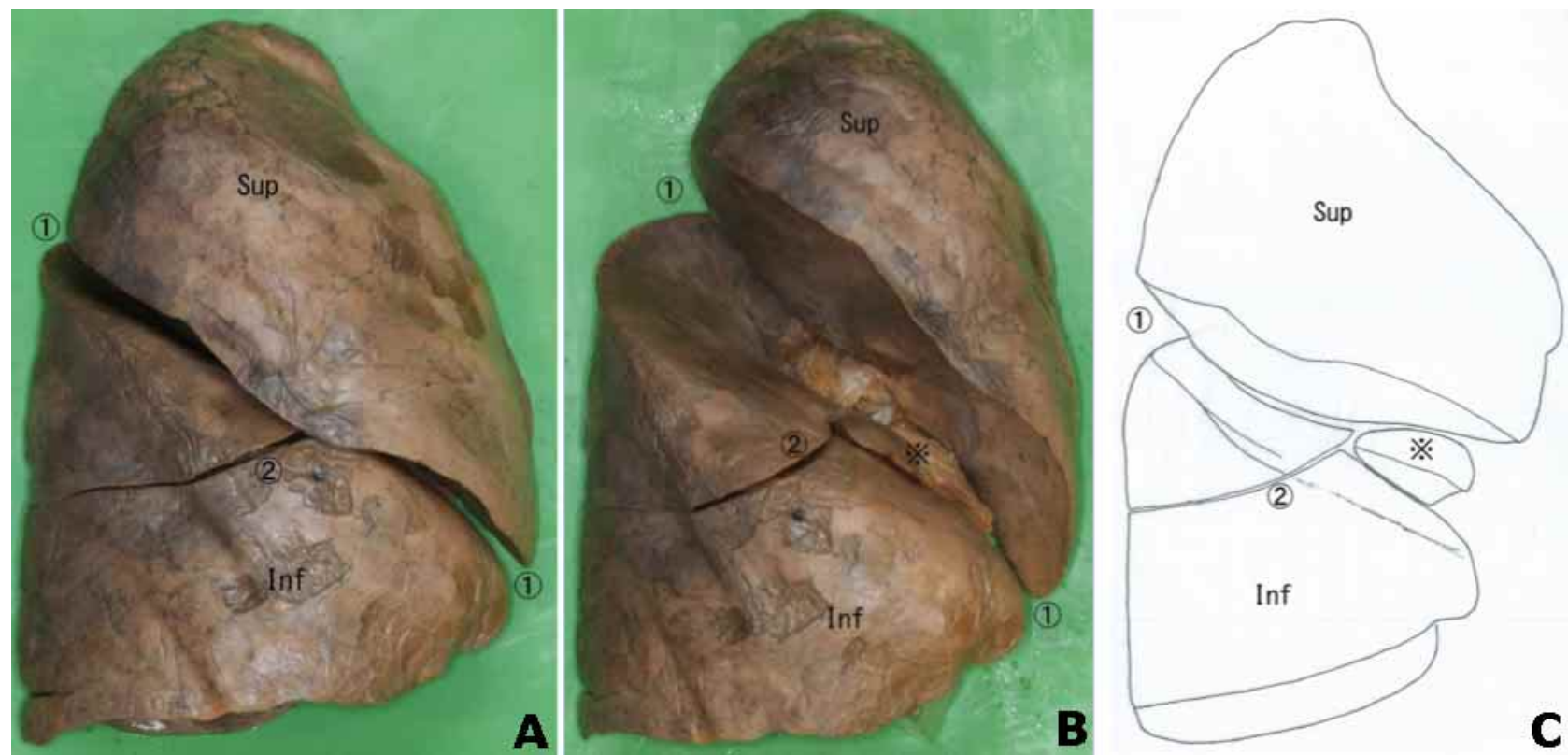

Fig. 1a Lateral aspect of the right lung (81-year-old Japanese female). In the present case, the horizontal fissure (,) was situated behind the oblique fissure (?). B. Lateral aspect of the right lung, the oblique fissure was opened. A small gland-like tissue $(*)$ was discovered within the oblique fissure. C. A drawing of Fig. 1b. The oblique fissure was opened. A small gland-like tissue $(*)$ had thin anterior edge and located/situated between the superior and inferior lobes.
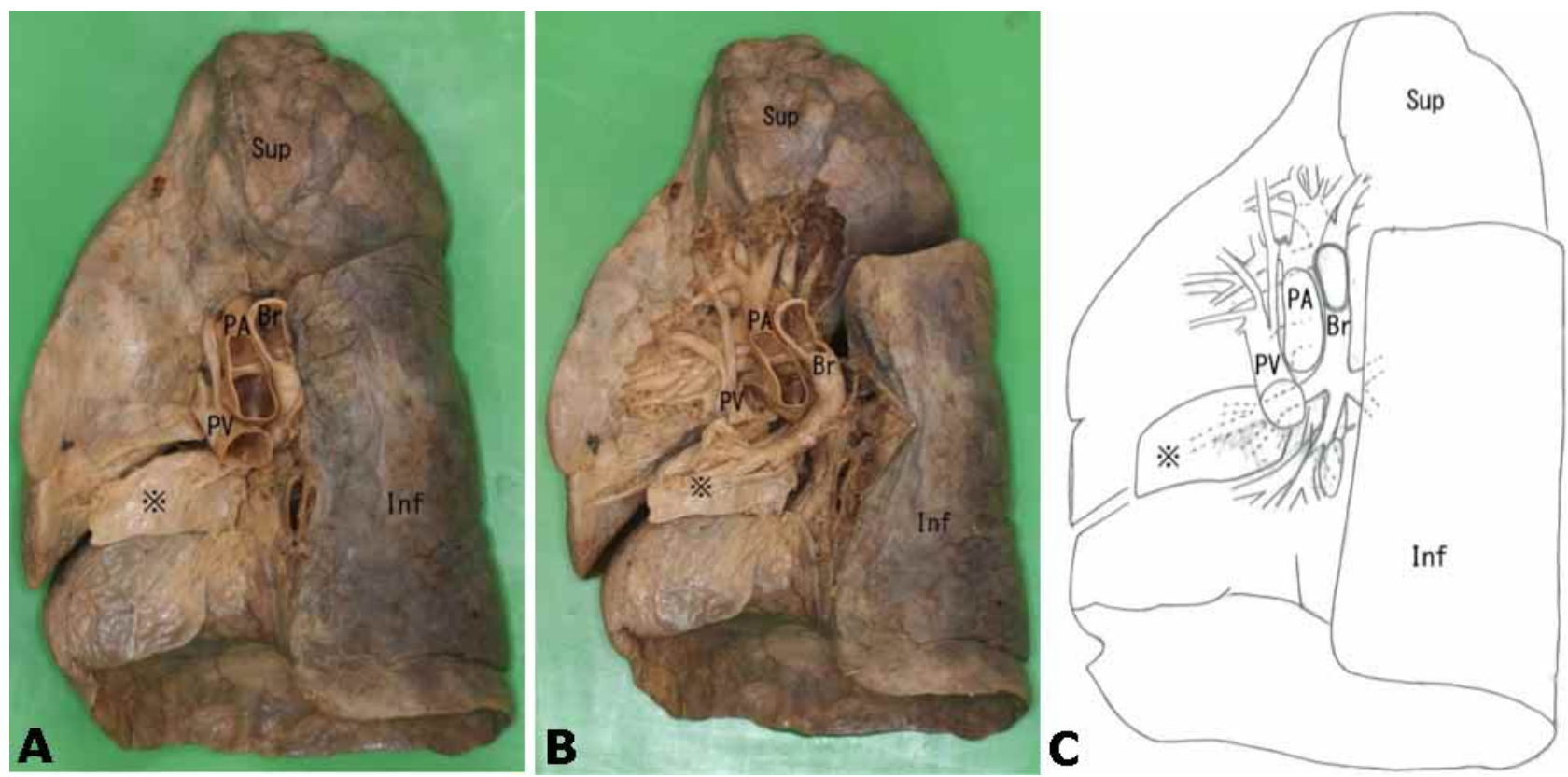

Fig. 2a Medial aspect of the right lung. The small gland-like tissue $(*)$ had an almost quadrangular shape. B. Medial aspect of the right lung, parenchymal tissue was removed to expose the intrapulmonary distribution of the bronchus and the pulmonary vessels. Distribution was also present in the small gland-like tissue (*). C. A drawing of Fig. 2b. The small gland-like tissue (*) was a hypoplastic middle lobe. $\mathrm{Br}$, bronchus; Hor, horizontal fissure; Inf, inferior lobe; Mid, middle lobe; Obl, oblique fissure; PA, pulmonary artery; PV, pulmonary vein; Sup, superior lobe; *, hypoplastic middle lobe; , oblique fissure; , horizontal fissure in the present case 


\section{DISCUSSION}

The horizontal fissure in the present case presented a unique opportunity to study anatomical development of the lung. In a normal right lung, the horizontal fissure is situated anterior to the oblique fissure. In contrast, in the present case, the horizontal fissure was situated posterior to the oblique fissure. Detection of the hypoplastic middle lobe within the oblique fissure led to the conclusion that, in the present case, an additional compensatory fissure had developed within the inferior lobe in place of the typical ventral horizontal fissure, and thatthe anterior horizontal fissure had completely disappeared as a result. The present case seems to be very rare. Bergman et al. reported a similar case of vestigial middle lobe within the oblique fissure, although there was no horizontal fissure. Ueyama et al. 2009, reported a case with hypoplastic middle and inferior lobes. They found that the middle lobe could not be seen exterior of the exposed lung. The cause of the hypoplasia was unknown. In the present case the hypoplastic middle lobe had the appearance of a gland. According to Arey (1966), the lung initially develops like a gland, and then expands, especially after birth. The bronchial and pulmonary vessels were distributed in the hypoplastic middle lobe in the present case. Therefore, it is likely that an anomaly developed in the middle lobe during the expansion of the lung. Bronchiectasis might be related to this anomaly. This case allows for the reconsideration of normal lung development.

OKAMOTO, K.; WAKEBE, T.; SAIKI, K.; MANABE, Y. \& TSURUMOTO, T. Un caso de fisura horizontal anómala y lóbulo medio hipoplásico del pulmón derecho. Int. J. Morphol., 35(2):651-653, 2017.

RESUMEN: Durante la práctica de disección para estudiantes de medicina en la Universidad de Nagasaki, se encontró una fisura horizontal y un lóbulo medio hipoplásico en el pulmón derecho de una mujer japonesa de 81 años de edad. En un pulmón derecho normal, la fisura horizontal está situada anterior a la fisura oblicua. Por el contrario, en el presente caso, la fisura horizontal estaba situada posterior a la fisura oblicua. Se identificó un pequeño lóbulo adicional en la superficie medial de este pulmón. Estaba situado en la parte medial de la fisura oblicua, y se determinó que era un pequeño lóbulo medio hipoplásico. Como resultado de la hipoplasia del lóbulo medio, la fisura horizontal original puede haber desaparecido de la superficie anterior. La fisura horizontal, en este caso, puede ser una fisura adicional compensatoria que se desarrolla dentro del lóbulo inferior. Esta fisura horizontal era incompleta, tanto en longitud como en profundidad. El pulmón izquierdo era normal. Este caso podría ser muy raro; Sin embargo, puede ayudar en la comprensión del desarrollo pulmonar normal. Por lo tanto, informamos este variación, incluyendo su ramificación bronquial y la distribución vascular.

PALABRAS ClaVE: Pulmón; Fisura horizontal del pulmón derecho; Lóbulo medio hipoplásico; Fisura oblicua; Anomalía.

\section{REFERENCES}

Arai, T. \& Shiozawa, M. Pulmonary Resections: Anatomy and Surgical Technique. Tokyo, Asakura Shoten, 1992.

Arey, L. B. Developmental Anatomy. A Textbook and Laboratory Manual of Embryology. Philadelphia, W. B. Saunders Co., 1966. pp.266-71.

Bergman, R. A.; Thompson, S. A.: Afifi, A. K. \& Saadeh, F. A. Compendium of Human Anatomic Variation. Text, Atlas and World Literature. Baltimore, Urban \& Schwarzenberg, 1988. pp.169-71.

Hollinshead, W. H. Anatomy for Surgeons. $2^{\text {nd }}$ ed. New York, Harper \& Row, 1971. pp.40-97.

Murakami, G. Lung. In: Sato, T. \& Akita, K. (Eds.). Anatomic Variations in Japanese. Tokyo, University of Tokyo Press, 2000. pp.737-45.

Ueyama, T.; Ito, T. \& Tsuruo, Y. Two cases of aberrant fissures of the lung. J. Wakayama Med., 60:143-5, 2009.

\author{
Corresponding author: \\ Keishi Okamoto \\ Department of Macroscopic Anatomy \\ Unit of Basic Medical Sciences \\ Graduate School of Biomedical Science \\ Nagasaki University \\ 1-12-4 Sakamoto \\ Nagasaki 852-8523 \\ JAPAN
}

E-mail: okamon@nagasaki-u.ac.jp

Received: 05-12-2016

Accepted: 27-02-2017 